\title{
Breeders and floaters use different habitat cover: should habitat use be a social status-dependent strategy?
}

\author{
Letizia Campioni • Rui Lourenço • \\ María del Mar Delgado • Vincenzo Penteriani
}

\begin{abstract}
In order to understand habitat requirements in territorial species, it is important to take into account the specific tasks and constraints associated with the different stages and social status of an individual life cycle (e.g. territorial breeder or nonterritorial floater). However, social status has rarely been taken into account in studies on habitat preference, selection and use. In the present study, we compare habitat characteristics near nesting sites of Eagle Owl Bubo bubo breeders with those of diurnal roosting places chosen by floating owls. As both nesting and roosting sites are important components of an individual's fitness (e.g. mating success vs. survival), we expected that the use of those locations would reflect the different cost-benefit trade-offs related to the status of breeder and floater, respectively. By analysing the structure of the forest stands and the landscape features surrounding both places at two spatial scales, we
\end{abstract}

Communicated by T. Gottschalk.

L. Campioni (\&) · R. Lourenço · M. d. M. Delgado ·

V. Penteriani

Department of Conservation Biology,

Biological Station of Doñana, C.S.I.C.,

c/Americo Vespucio s/n, 41092 Seville, Spain

e-mail: letiziacampioni@hotmail.com; letizia@ebd.csic.es

\section{R. Lourenço}

LabOr-Laboratory of Ornithology and Institute

of Mediterranean Agricultural and Environmental Sciences,

University of Évora, 7002-554 Évora, Portugal

\section{M. d. M. Delgado}

Metapopulation Research Group, Department of Biosciences, University of Helsinki, 00014 Helsinki, Finland

\section{Penteriani}

Finnish Museum of Natural History, Zoological Museum, University of Helsinki, 00014 Helsinki, Finland found that: (1) breeders and the floaters used forest stands with a different vertical structure; compared with the floaters, the breeders used more mature stands characterised by higher trees; (2) as expected, breeders and floaters did not show any specific habitat use at the landscape scale. Our results showed a clear discrepancy in habitat use according to social classes, suggesting social tasks/constraints (successful reproduction vs. overcoming dispersal costs) as potential determinants of two divergent strategies in habitat use.

Keywords Habitat use - Social status - Floaters - Eagle Owl · Bubo bubo · Trade-off

\section{Zusammenfassung}

Brü ter und Nichtbrü ter nutzen unterschiedliche Habitatbedeckung: sollte Habitatnutzung eine Strategie sein, die vom sozialen Status abhä ngt?

Um Habitatansprüche territorialer Arten zu verstehen, ist es wichtig, die spezifischen Aufgaben und Einschränkungen zu berücksichtigen, die mit unterschiedlichen Abschnitten und sozialen Status im Lebenszyklus eines Individuums (z. B. territorialer Brüter oder nicht territorialer Nichtbrüter) zusammenhängen. Der soziale Status ist in Studien über Habitatpräferenzen, -selektion und -nutzung jedoch nur selten in Betracht gezogen worden. In der vorliegenden Studie vergleichen wir Habitateigenschaften in der Nähe von Niststandorten brütender Uhus (Bubo bubo) mit denen von Ruheplätzen, die nicht brütende Eulen tagsüber nutzen. Da sowohl Brut- als auch Ruheplätze wichtige Komponenten der individuellen Fitness (z. B. Paarungserfolg versus Überleben) sind, erwarteten wir, dass die Nutzung dieser Plätze die unterschiedlichen Kosten-Nutzen-Abwägungen, die den Status als Brüter bzw. Nichtbrüter betreffen, 
wiederspiegeln würde. Indem wir die Struktur der Waldbestände und die beide Plätze umgebenden Landschaftsmerkmale auf zwei räumlichen Ebenen analysiert haben, fanden wir heraus, dass (1) Brüter und Nichtbrüter Waldbestände mit unterschiedlicher vertikaler Struktur nutzten-verglichen mit Nichtbrütern nutzten die Brüter ältere Bestände, die sich durch höhere Bäume auszeichneten, und dass (2) wie erwartet Brüter und Nichtbrüter keinerlei spezifische Habitatnutzung bezüglich des Landschaftstyps zeigten. Unsere Ergebnisse zeigten einen klaren Unterschied in der Habitatnutzung entsprechend dem sozialen Status, was darauf hindeutet, dass soziale Aufgaben/ Einschränkungen (erfolgreiche Fortpflanzung versus Überwinden der Kosten der Ausbreitung) potenzielle Determinanten zweier unterschiedlicher Habitatnutzungsstrategien darstellen.

\section{Introduction}

The habitat requirements used during an animal's lifetime reveal the likelihood that the animal will select a given item if offered alternative choices on an equal basis (Beyer et al. 2010). Habitat selection involves different aspects of the individual life history and has strong implications for individual fitness (e.g. survival, fecundity, and mating success; Millon et al. 2010; Morosinotto et al. 2010). The overall decision process implies a balance of costs and benefits from the earliest actions of an individual as an inexperienced juvenile to the subsequent actions of the individual as an experienced adult. Frequently, individuals or species have been associated with specific habitat types, e.g. under the assumption that they should occupy the same habitats over their whole lifetime (Dale and Christiansen 2010). However, there is evidence of a degree of individual flexibility in habitat preferences, of the use and selection over the different stages of the individual life cycle (Terborgh 1989; Kozakiewicz 1995; Law and Dickman 1998). For example, shifts in habitat preference, selection and use have been observed among fledglings as well as dispersing and breeding birds (e.g. Ferrer and Harte 1997; King et al. 2006; Campioni et al. 2010; Dale and Christiansen 2010; Delgado et al. 2010).

The habitat needs of territorial breeders has been extensively quantified for many species, whereas the current lack of understanding of the behavioural strategies of the floating individuals of a population during natal dispersal still represents an information need in population ecology (Penteriani et al. 2011a, b). Very few studies have been able to address habitat use in terms of cost-benefit considerations and behavioural tactics related to the social status of individuals, e.g. the hypothesis that the individual's needs during its lifespan can vary with its social status (e.g. Brown and Long 2007; Campioni et al. 2010; Penteriani et al. 2011a, b). A territorial breeder, which settles in a more established social context principally involving interactions with stable neighbours, needs to accomplish specific duties primarily related to its territory ownership and diverse reproductive tasks. In contrast, most floaters are dispersing individuals leading a transient life. In this study, we defined floaters as the entire pool of dispersing individuals independent of age because: (1) they are sexually mature when less than 1 year old, and (2) dispersing owls remained 'floating' in the vicinity of the breeding population during both phases of dispersal (Penteriani et al. 2012). Although the definition of floaters is not commonly based on their dispersal status, floating individuals moving close to or within nesting sites may also be considered as dispersers until they first reproduce (Penteriani et al. 2011a, b).

Although floaters may settle in a more or less fixed area, they do not show any territorial behaviour (e.g. Rohner 1997; Delgado et al. 2009a; Penteriani and Delgado 2012). Consequently, the major threats faced by non-breeding individuals are imposed by dangerous travel through unknown landscapes and by frequent encounters with changing social contexts, which can drive floaters' behavioural decisions at different temporal and spatial scales (Smith 1978; Arcese 1989; Stutchbury 1991; Tobler and Smith 2004; Delgado and Penteriani 2008; Delgado et al. 2009a; Penteriani and Delgado 2011). Hence, the discrepancies among the specific tasks and constraints associated with each social status (reproducing successfully vs. overcoming dispersal costs) can potentially determine divergent habitat use strategies. In particular, because the characteristics of the nesting site are an important component of the breeder's fitness and the choice of diurnal roosting places during dispersal may affect floater survival, we may expect that the use of these locations would reflect the different cost-benefit trade-offs related to the social status of different individuals.

To compare possible status-dependent differences in habitat use between floaters and breeders, we took advantage of an unusual opportunity furnished by the recent process of colonisation by a top predator, the Eagle Owl (Bubo bubo), in the Doñana National Park (henceforth Doñana), Andalusia, southern Spain (more details in Penteriani et al. 2008a; Lourenço et al. 2011). In this area, the nesting places and diurnal roosts of breeders and the diurnal roosting places of floaters are always located in forested patches, i.e. a similar type of cover that may potentially show different age structures and different degrees of extension for the two social classes. Thus, we focus here on the individual habitat use based on the following: (1) the structure of the forest stands, and (2) the 
landscape features surrounding both places, where (1) breeders reproduce and roost, and (2) floaters roost. While the adults may 'prefer' a particular habitat or forest structure and select for it, it does not really follow that juveniles or floaters are preferentially selecting the remaining habitat. The habitat used by the juveniles may principally be the use of what is left to them given that the paired adults have selected the optimal hunting and nesting habitat. For this reason, in the context of this work, we preferred to adopt the more neutral term 'habitat use' rather than 'preference' when referring to the juveniles. Our main expectation is that habitat use will show differences related to the different tasks/constraints peculiar to each social group. In particular, we expect that: firstly, the structure of the forest stands used by breeding individuals primarily reflects the need of the breeders to fly easily within the breeding stand during the entire reproductive period, when they must care for nestlings (e.g. when the breeders are carrying a prey item to the nest) and must subsequently care for fledglings during the post-fledging dependence period, i.e. breeders prefer mature forest stands characterised by old, high and widely spaced trees, and secondly, the floaters' stand use primarily reflect the cost of dispersing to new environments, e.g. the need to avoid encounters with territory holders and potential predators, as well as reduce physical aggression/mobbing from other raptor species (Lourenço et al. 2011). Thus, the stand use of floaters might be directed towards denser and more closely spaced stands of forest than the stand preference of breeders. The forest patches used by the floaters should provide safer conditions than more open areas. Additionally, because of the abovecited needs and constraints acting at the scale of the entire stand, we expect, thirdly, no differences at the broader spatial scale of the landscape surrounding the nests and roosts, although previous research in Doñana has revealed crucial elements of habitat heterogeneity within this study area: (1) Doñana scrublands are the preferred habitat type frequented by the European Rabbit Oryctolagus cuniculus (Palomares et al. 2001; Fernández 2005), the Eagle Owl’s main prey, and (2) marshlands are among the most productive areas of Doñana and offer the greatest prey richness (Ferrer and Bissom 2003; Sergio et al. 2005).

\section{Methods}

\section{Study area}

This study was conducted in an $870-\mathrm{km}^{2}$ area in southwestern Spain. Most of the area is included in the Doñana National and Natural Parks (Fig. 1), a natural area bounded by the Atlantic Ocean on the west, by the Guadalquivir River to the east, and by crops extending several kilometres to the north towards the Sierra Morena Mountains. This area is flat and generally near sea level, with a maximum elevation of $106 \mathrm{~m}$ (for additional details, see Fernández et al. 2003). Three ecosystem types are predominant: fixed dunes, mobile dunes and marshes. The vegetation in the fixed dunes consists of autochthonous Mediterranean scrubland in a mixture of different stages of degradation (Castroviejo 1993). Many areas are dominated by plantations of pines (Pinus pinea), with variable understory vegetation. The scrubland is dominated by Halimium halimifolium and Ulex spp. or Erica spp. heaths depending on the depth of the water. More mature scrubland areas with Pistacia lentiscus and Myrtus communis are found primarily in the north. A number of other areas have been transformed by Eucalyptus camaldulensis plantations introduced during the first half of the twentieth century.

\section{Data collection}

From 2005 through 2008, we followed the process of colonisation of Doñana by Eagle Owls. The first breeding of this species in this area was recorded in 1999 (Penteriani et al. 2008b). Every year, we systematically surveyed the study area and conducted a census of the newly settled population using a combination of different methods including: (1) passive auditory surveys at sunrise and sunset from October through February, when the vocal activity of adults was most intense; (2) visiting forest and open patches to detect nests, pellets, and feeding perches; and (3) passive auditory surveys of calling young, conducted from the stage at which the chicks were approximately 100 days old until they began to disperse (August-September in our study area). We located 15 breeding sites and 4 areas potentially suited for reproduction and widely spaced among these sites, with a mean nearest-neighbour distance of approximately $3.9 \pm 0.4 \mathrm{~km}$ (mean $\pm \mathrm{SD}$ ) (Penteriani et al. 2008a, b). In Doñana, the Eagle Owl used to nest in free or deserted nest structures previously built on trees by storks, herons and other raptor species, as well as on the ground (Penteriani et al. 2012). However, we considered that the availability of suitable stick nests in the study area should not significantly influence habitat selection because: (1) the Eagle Owls in Doñana can also nest on the ground (e.g. during the 2006-2008 period, we recorded two breeding events on the ground of a forested patch); (2) this species is extremely eclectic in nest site selection, and thus locations of suitable stick nests should not represent a limiting factor in our study area; (3) because of the high density of diurnal raptors breeding places in Doñana (Sergio et al. 2005; Casado et al. 2008), there are suitable nest for Eagle Owl breeding almost everywhere in this area; and (4) Doñana Eagle Owls breed earlier in the 
Fig. 1 Distribution of the 15 nesting sites (grey squares) and 75 floater's roosting sites (black circles) of the Eagle Owl (Bubo bubo) in the Doñana National and Natural Parks

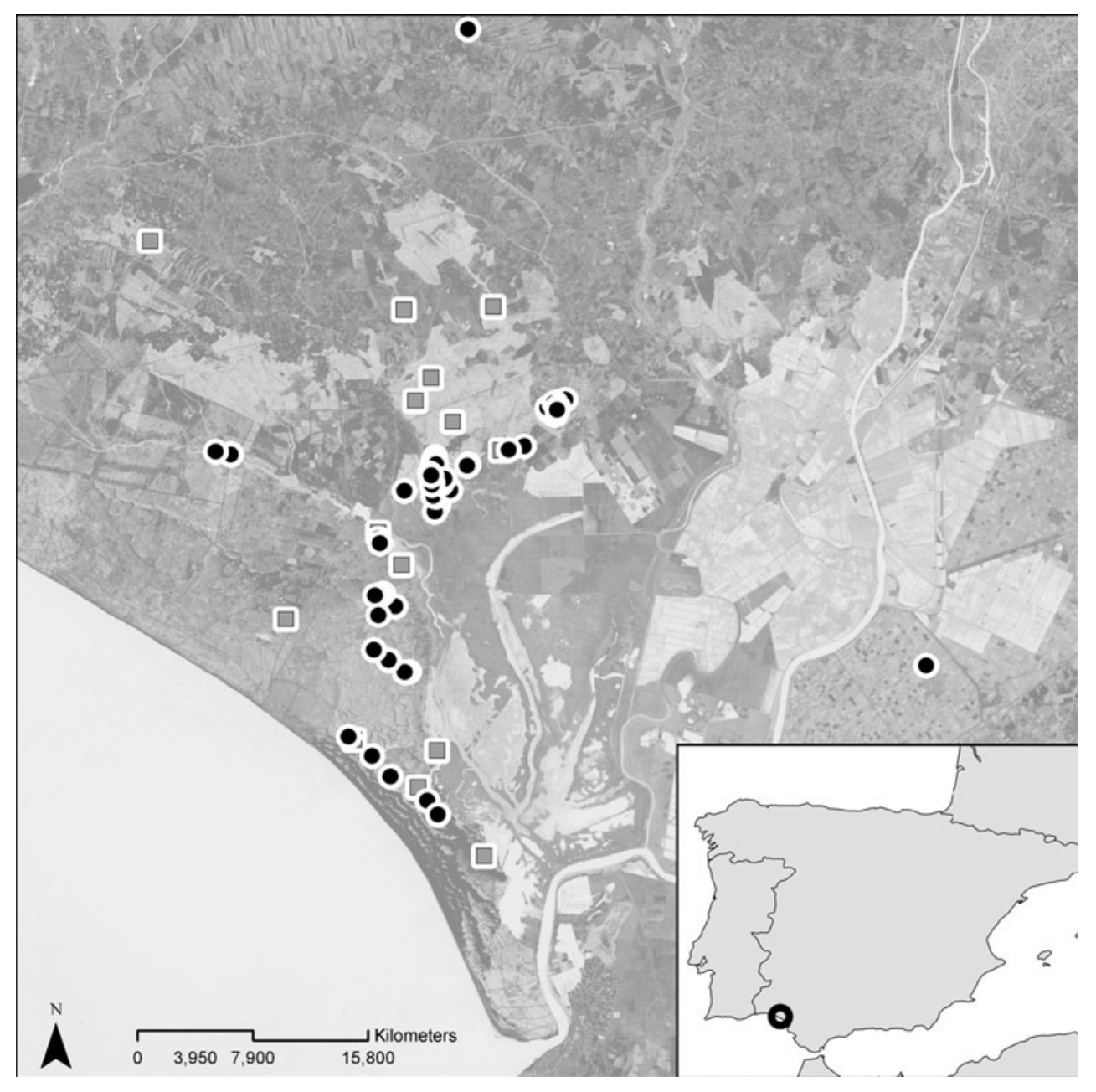

season than raptors and storks, so the majority of nests are available at the time the owls want to use them.

During the 3 years of the study, we were able to tag and then radiotrack 5 breeding adults (2006: $\mathrm{n}=1 ; 2007: \mathrm{n}=3$; 2008: $\mathrm{n}=1$ ) and 32 juveniles (2006: $\mathrm{n}=9$; 2007: $\mathrm{n}=15$; 2008: $n=8$ ) from 11 nests. The owlets were tagged at the nest when they were approximately 35 days old, 5-10 days prior to the onset of fledging. They were aged following Penteriani et al. (2004) and were sexed by molecular procedures using DNA extracted from blood (Griffiths et al. 1998). They were fitted with a Teflon ribbon backpack harness that carried a 30-g radio transmitter (Biotrack, Wareham, Dorset, UK) with a mercury posture sensor. Because the young were still growing, the backpacks were adjusted so that the Teflon ribbon could expand (Delgado and Penteriani 2007). The manipulation was always safe: after 7 years of continuous radiotracking of both breeders and floaters, we never recorded a potential adverse effect of backpacks on the birds or on breeding performance (Delgado and Penteriani, unpublished data). The backpacks were not removed after the study due to the difficulty of retrapping the same individual (Penteriani and Delgado, unpublished data). The locations of the radio- marked adults and juveniles were recorded with a triangulation method with an accuracy of $83.5 \pm 49.5 \mathrm{~m}$ (mean \pm SE) (Penteriani and Delgado 2008) using three-element hand-held Yagi antennas (Biotrack) with Stabo (XR-100) portable ICOM receivers (IC-R20). The accuracy value was calculated when, after a triangulation, we needed to locate the individual exactly to manipulate it during field experiments (e.g. Penteriani et al. 2007) or to record the cause of mortality if it died. The juveniles were located weekly during the daytime (when the owls were at their diurnal roost sites; Delgado et al. 2009a) from the beginning of natal dispersal ( $* 170$ days old; for details on the calculation of the beginning of dispersal, see Delgado and Penteriani 2008) until either the death of the individual or the failure of the battery transmitter (*1.5 to $* 2.5$ years).

Habitat structure at the stand level

Following stand analyses in Penteriani and Faivre (1997), we characterised the structure of the forest stand within a 50-mdiameter (surface $=0.39$ ha) plot around (1) the nest tree ( $\mathrm{n}=15$ nesting sites), and (2) the floaters' weekly locations 
( $\mathrm{n}=17$ roosting locations of different dispersers, i.e. a random selection from a total of 75 floaters' roosts, performed to avoid pseudoreplication and spatial autocorrelation problems). We were confident that a 50-m-diameter plot allowed the depiction of the stand structure, mainly because: (1) of the homogeneity of the artificial Doñana forest stands, and (2) the small area of some of the forest patches occupied by the species for both breeding and roosting. Measurements were made using four transects per plot. Each transect formed a $90^{\circ}$ angle with the two adjacent transects. The transects were placed with one end at the centre of the plot and were arranged so that one transect extended towards each of the four cardinal points (N, S, E, W). Based on the line intercept method (Bonham 1989), three parameters were measured on the trees intercepted by the transect paths: (1) tree height (m), (2) diameter at breast height (circumference/3.14), and (3) tree density (trees number/plot area). Moreover, we calculated the aerial flight space inside the stand for each plot, i.e. the free volume inside the forested stand available and necessary for owl flights near the nest and the roost locations, as in Penteriani and Faivre (1997). The aerial flight space was represented by a square-based parallelepiped whose major sides were defined by the heights of the tree trunks measured from the ground to the lowest limb and whose basal sides were defined by the distances between the trunks. Finally, we calculated the canopy cover (i.e. the percentage of sky obstructed by vegetation above the centre of the plot) from black-and-white photographs (18 mm, f/3.5 lens) of the canopy cover with a 50950 grid of pixels arranged in a square that was the same size as the photograph (Penteriani and Delgado 2009a; Penteriani and Faivre 1997).

Habitat structure and composition at the landscape level

We characterised the landscape structure and composition within a circular plot with a radius of $1,900 \mathrm{~m}$. These plots were centred on the nesting and roosting sites. The area of the plot corresponds to the mean home range size (MCP $95 \%)$ calculated employing radiotracking data on 4 of the 5 tagged breeders within Doñana. The landscape characteristics were measured by constructing the intersection of a digital layer including those circular plots with a map of land-cover elements (scale 1:25.000; Junta de Andalucia, Consejerìa de Medio Ambiente, 2003). The landscape composition was classified according to the following 7 categories: tall scrub, low scrub, pasture, woodland, marshes, sand dune and crops. In addition, we characterised landscape structures by calculating: (1) the number of patches, (2) the Shannon index of habitat diversity, (3) the edge density as a proxy of habitat heterogeneity (Anderson et al. 2005), and (4) for each nest tree and roost site, the distance (m) to the nearest marshland. In our study area, the proximity of marshes is associated with an increase in the richness of rabbits (Fernández et al. 2003; Palomares et al. 2001), the main prey of Eagle Owls (Penteriani et al. 2008a, b). The GIS application ArcView 3.2 and its extension Patch Analyst (Elkie et al. 1999) were used for the analyses of landscape characteristics.

Data analysis

We applied two General Linear Models (GLMs) with a distribution belonging to the binomial family. The dependent variable was social status (breeder $=1$, floater $=0$ ). In the first model, we analysed habitat use at the forest stand level. The previously detailed descriptors of the stand structure represented the explanatory variables (Table 1). In the second model, we investigated habitat use at the landscape level, employing habitat composition and structure as the explanatory variables (Table 1 ). To reduce collinearity and the number of explanatory variables, pairs of strongly inter-correlated variables ( $\mathrm{\Gamma}$ [ 0.6 ) were considered to be estimates of a single underlying factor. Only one of the two variables, usually the one perceived as more important by the study organism, was retained for analysis. Before performing any analysis, we tested for spatial autocorrelation among the locations of the breeders and floaters. For this purpose, we used a Moran's I test (Cliff and Ord 1981) under randomisation conditions at both the stand and the landscape level. No patterns of spatial autocorrelation were present in our data (stand: Moran's I statistic standard deviate $=-0.0735, \quad \mathrm{P}$ value $=0.53$; landscape: Moran's I statistic standard deviate $=0.2429$, $\mathrm{P}$ value $=0.40)$. As suggested by Zuur et al. (2009), model simplification was performed by backward selection of variables from the full model. To find the minimal adequate model, models were compared using the Likelihood Ratio Test (LRT) approach employing the anova command in the R environment (R Development Core Team 2009). Logistic regressions were performed with the glm function in the $\mathrm{R}$ "stats" package. The percentage of deviance explained was calculated as follows: deviance (null model) - deviance (selected model)/deviance (null model) 9100. The means \pm SD and the $95 \% \mathrm{CI}$ are given in addition to these values. Statistical significance was set at a $\backslash 0.05$.

\section{Results and discussion}

The forest stand structure was analysed for a total of 32 locations (15 nesting places and 17 roosting places of floaters). The breeders and the floaters preferred forest stands with a different vertical structure. Compared with the floaters, the breeders preferred more mature stands characterised by higher trees (GLM tree mean height estimate \pm SEM: $0.455 \pm 0.168 ; \mathrm{P}=0.007 ; 95 \%$ 
Table 1 Characterisation of the forest stand and landscape of breeder's nesting places and floater's roosting places of Eagle Owls employed in the GLM analyses

\begin{tabular}{|c|c|c|c|c|}
\hline \multirow[t]{3}{*}{ Explanatory variables } & \multicolumn{4}{|l|}{ Individual status } \\
\hline & \multicolumn{2}{|l|}{ Breeder } & \multicolumn{2}{|l|}{ Floater } \\
\hline & Mean \pm SD & Range & Mean \pm SD & Range \\
\hline \multicolumn{5}{|l|}{ Stand plot level } \\
\hline Tree height (m)* & $16.35 \pm 3.5$ & $11.88-21.24$ & $9.70 \pm 2.09$ & $5.84-13.12$ \\
\hline Diameter at breast height (m) & $0.52 \pm 0.2$ & $0.25-0.87$ & $0.40 \pm 0.15$ & $0.22-0.77$ \\
\hline Density & $0.02 \pm 0.02$ & $0.0001-0.06$ & $0.03 \pm 0.02$ & $0.01-0.08$ \\
\hline Canopy cover (\%) & $47.9 \pm 23.3$ & 11.8-96.6 & $65.1 \pm 32.7$ & 17.7-99.7 \\
\hline Flight space $\left(\mathrm{m}^{3}\right)$ & $1,745.0 \pm 1,553.2$ & $106.8-5,888.0$ & $1,099 \pm 2,061$ & $150.2-8,677$ \\
\hline \multicolumn{5}{|l|}{ Landscape plot level } \\
\hline Dense scrub (\%) & $24.1 \pm 16.7$ & $1.4-56.5$ & $33.7 \pm 12.4$ & $12.8-59.6$ \\
\hline Disperse scrub (\%) & $3.7 \pm 3.6$ & $0.01-9.8$ & $2.7 \pm 2.6$ & $0.03-8.71$ \\
\hline Pasture (\%) & $6.1 \pm 12.0$ & $0.1-44.0$ & $10.5 \pm 10.5$ & $0.4-26.9$ \\
\hline Woodland (\%) & $40.5 \pm 24.6$ & $2.7-73.2$ & $30.9 \pm 20.2$ & $0.3-61.6$ \\
\hline Marshes (\%) & $11.6 \pm 17.2$ & $0.01-52.7$ & $4.9 \pm 6.3$ & $0.05-21.2$ \\
\hline Sand dune (\%) & $6.2 \pm 10.2$ & $0.01-24.3$ & $2.7 \pm 7.9$ & $0.01-26.8$ \\
\hline Crops (\%) & $9.4 \pm 15.4$ & $0.01-48.0$ & $7.8 \pm 14.6$ & $0.01-40.6$ \\
\hline Edge density (m/ha) & $61.0 \pm 32.2$ & $18.9-113.4$ & $52.9 \pm 31.1$ & $20.1-101.7$ \\
\hline Shannon index of diversity & $0.7 \pm 0.3$ & $0.2-1.2$ & $0.7 \pm 0.3$ & $0.2-1.3$ \\
\hline Distance to marshes (m) & $1,028.0 \pm 916.0$ & $37.6-3,637.0$ & $908.4 \pm 698.9$ & $0.01-2,384.0$ \\
\hline
\end{tabular}

* $\mathrm{P}=0.007$ in the GLM analysis

CI: $0.186-0.865$; \% deviance explained = 33; Table 1 ; Fig. 2). Although all the other parameters we took into account at the stand level did not show any significant difference between breeders and floaters, we consider it important to highlight that all of the stand measurements depicted a more mature and open stand structure for breeders (Table 1).

At the landscape level (after accounting for outliers), we identified a total of 31 plots $(n=14$ for breeders and $\mathrm{n}=17$ for floaters). Breeders and floaters did not show any
Fig. 2 Point pattern representation of the original nest and roost locations preferred by breeder and floater Eagle Owls at forest stand level. Bubble size represents the vertical structure and is proportional to the mean tree height characterising breeding territories and roosting areas. Bubble size is automatically drawn taking into account the range of values of tree height (min-max values). Bubble centre is the $\mathrm{X}$ and $\mathrm{Y}$ coordinates in UTM system of each location. a Breeders and floaters locations; b breeders only; c floaters' locations

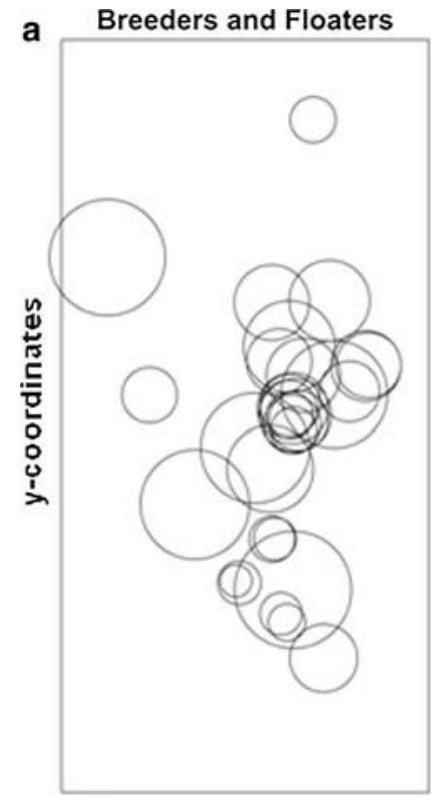

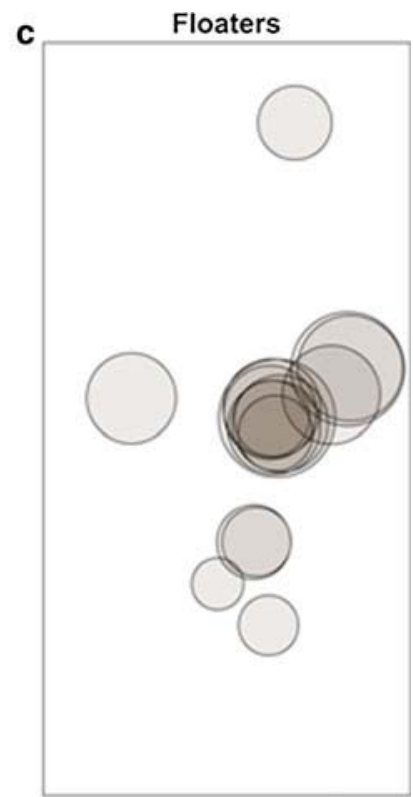


specific habitat use at the level of the landscape surrounding their nesting and roosting places (P $\mathbf{\Gamma} 0.1$ in all cases; Table 1).

Our findings mainly suggest that: (1) individuals of the same population but differing in social status can show different habitat use, and (2) the structure of the forested patches could have played a more important role than vegetation type (as also highlighted by Dale and Christiansen 2010) in determining the recorded patterns of habitat use.

The different patterns of habitat use of breeders versus floaters (see also Campioni et al. 2010) may be explained by the tasks and constraints associated with these differences in status. For reproduction occurring within forested stands, the different activities that breeders perform in the area surrounding the nest specifically require easy access to the nest. This access is provided by the more open structure offered by the oldest stands: the preference for mature trees as a breeding stand has been recorded in many other raptor species as, for example, the Goshawk (Accipiter gentilis; Penteriani 2002) and the White-tailed Eagle (Haliaeetus albicilla; Racovic and Mikuska 2009).

In contrast, non-territorial floaters are free from these temporal and spatial constraints. They depend primarily on foraging, frequently in unfamiliar areas, and on conspecific avoidance. The high costs associated with diurnal activity are shown by the highly cryptic behaviour of the Eagle Owl and of many owl species during the day and by the aggressive reactions of other birds of prey towards the owls (Sunde et al. 2003; Lourenço et al. 2011). The choice of a safe area for diurnal inactivity (when owls are particularly vulnerable to predation or harassment by mobbers) can represent an adaptive strategy to overcome the costs of dispersal (Stamp et al. 2005). This phenomenon may be even more apparent if owls and diurnal raptors can overlap in space and time. Such overlap occurs in our study area, where the high densities of diurnal raptors increase the risk of diurnal raptor attacks on roosting Eagle Owls (Lourenço et al. 2011). Indeed, it has been shown that the ways in which animals are distributed relative to conspecifics (and in our case relative to heterospecifics) often represent a trade-off between the costs and benefit of proximity, e.g. predator attraction versus the dilution effect (Fero and Moore 2008).

We can expect the strategy of the territorial breeder to be directed to maximise individual benefits by selecting suitable breeding conditions that provide long-term individual benefits and increase fitness. In contrast, the strategy of the non-territorial floater appears to minimise the shortterm negative effects of natal dispersal through behavioural mechanisms, such as specific cover use. Finally, we cannot discard the possibility that the behavioural strategies of floaters can be actuated through habitat-mediated avoidance or temporal segregation mechanisms (e.g. Sergio et al. 2007). As an ultimate consequence, habitat use patterns may then involve the interaction of multiple social, behavioural and ecological determinants with direct ecological and evolutionary consequences for population dynamics and colonisation (Clobert et al. 2001, 2009).

Acknowledgments The first draft of the manuscript has been greatly improved thanks to the comment of Pete Bloom and an anonymous referee. We are grateful to O. Mora, C. Bettega and F. Goitre for their help during the field work. Funding for this study was provided by the research project from Consejería de Medio Ambiente, of the Junta de Andalucía (research project no. 700/2005/ M/00./). During this work L.C. was supported by a doctoral grant (JAE pre-doc from the C.S.I.C.). Owls were trapped and marked under the Junta de Andalucía-Consejería de Medio Ambiente permit nos. SCFFSAFR/GGG RS-260/02 and SCFFS-AFR/CMM RS-1904/02.

\section{References}

Anderson DP, Forester JD, Turner MG, Frair JL, Merrill EH, Fortin D, Mao JS, Boyce MS (2005) Factors influencing female home range sizes in elk (Cervus elaphus) in North American landscapes. Landsc Ecol 20:257-271. doi:10.1007/s10980-0050062-8

Arcese P (1989) Intrasexual competition, mating systems and natal dispersal in song sparrows. Anim Behav 38:958-979. doi: 10.1016/S0003-3472(89)80137-X

Beyer HL, Haydon DT, Morales JM, Frair JL, Hebblewhite M, Mitchell M, Matthiopoulos J (2010) The interpretation of habitat preference metrics under use-availability designs. Phil Trans R Soc Lond B 365:2245-2254. doi:10.1098/rstb.2010.0083

Bonham CD (1989) Measurements for terrestrial vegetation. Wiley, New York

Brown DR, Long JA (2007) What is a winter floater? Causes, consequences, and implication for habitat selection. Condor 109:548-565. doi:10.1650/8351.1

Campioni L, Delgado MM, Penteriani V (2010) Social status influences microhabitat selection: breeder and floater eagle owls Bubo bubo use different post sites. Ibis 152:569-579. doi: 10.1111/j.1474-919X.2010.01030.X

Casado E, Suárez-Seoane S, Lamelin J, Ferrer M (2008) The regulation of brood reduction in booted eagles Hieraaetus pennatus through habitat heterogeneity. Ibis 150:788-798. doi: 10.1111/j.1474-919X.2008.00862.x

Castroviejo J (1993) Mapa del Parque Nacional de Doñana. Consejo Superior de Investigaciones Científicas y Agencia de Medio Ambiente de la Junta de Andalucía, Madrid

Cliff AD, Ord JK (1981) Spatial processes. Models and applications. Pion, London

Clobert J, Danchin E, Dhondt AA, Nichols JD (2001) Dispersal. Oxford University Press, Oxford

Clobert J, Le Galliard JF, Cote J, Meylan S, Massot M (2009) Informed dispersal, heterogeneity in animal dispersal syndromes and the dynamics of spatially structured populations. Ecol Lett 12:197-209. doi:10.1111/j.1461-0248.2008.01267.x

Dale S, Christiansen P (2010) Individual flexibility in habitat selection in the ortolan bunting Emberiza hortulana. J Avian Biol 4:266-272. doi:10.1111/j.1600-048X.2009.04824.x

Delgado MM, Penteriani V (2007) Vocal behaviour and neighbour spatial arrangement during vocal displays in eagle owls. J Zool 271:3-10. doi:10.1111/j.1469-7998.2006.00205.x 
Delgado MM, Penteriani V (2008) Behavioral states help translate dispersal movements into spatial distribution patterns of floaters. Am Nat 172:475-485. doi:10.1086/590964

Delgado MM, Penteriani V, Nams VO, Campioni L (2009a) Changes of movement patterns from early dispersal to settlement. Behav Ecol Socbiol 64:35-43. doi:10.1007/s00265-009-0815-5

Delgado MM, Penteriani V, Nams VO (2009b) How fledglings explore surroundings from fledging to dispersal? A case study with eagle owls. Ardea 97:7-15. doi:10.5253/078.097.0102

Delgado MM, Penteriani V, Revilla E, Nams VO (2010) The effect of phenotypic traits and external cues on natal dispersal movements. J Anim Ecol 79:620-632. doi:10.1111/j.1365-2656.2009. 01655.x

Elkie P, Rempel R, Carr A (1999) Patch analyst user's manual: a tool for quantifying landscape structure. Ont Min Natur Resour Northwest Sci Technol. Thunder Bay, Ontario http://flash. lakeheadu.ca/_rrempe/patch/

Fernández N (2005) Spatial patterns in European rabbit abundance after a population collapse. Landsc Ecol 20:897-910. doi: 10.1007/s10980-004-3976-7

Fernández N, Delibes M, Palomares F, Mladenoff DJ (2003) Identifying breeding habitat for the Iberian lynx: inferences from a fine-scale spatial analysis. Ecol Appl 13:1310-1324. doi: 10.1890/02-5081

Fero K, Moore PA (2008) Social spacing of crayfish in natural habitats: what role does dominance play? Behav Ecol Sociobiol 62:1119-1125. doi:10.1007/s00265-007-0540-x

Ferrer M, Bissom I (2003) Age and territory-quality effects on fecundity in the Spanish imperial eagle (Aquila adalberti). Auk 120:180-186. doi:10.1642/0004-8038(2003)120[0180:AATEOF]2.0.CO;2

Ferrer M, Harte M (1997) Habitat selection by immature Spanish imperial eagles during the dispersal period. J Appl Ecol 34:1359-1364

Griffiths R, Double MC, Orr K, Dawson RJG (1998) A DNA test to sex most birds. Mol Ecol 7:1071-1075. doi:10.1046/j.1365-294x. 1998.00389.x

King DI, Degraaf RM, Smith ML, Buonaccorsi JP (2006) Habitat selection and habitat-specific survival of fledgling ovenbirds (Seiurus aurocapilla). J Zool 269:414-421. doi:10.1111/j.1469-7998. 2006.00158.x

Kozakiewicz M (1995) Resource tracking in space and time. In: Hansson L, Fahrig L, Merriam G (eds) Mosaic landscapes and ecological processes. Chapman and Hall, London, pp 136-148

Law BS, Dickman CR (1998) The use of habitat mosaics by terrestrial vertebrate fauna: implications for conservation and management. Biol Conserv 7:323-333. doi:10.1023/A:1008877611726

Lourenço R, Penteriani V, Delgado MM, Marchi-Bartolozzi M, Rabaça JE (2011) Kill before being killed: an experimental approach supports the predator-removal hypothesis as a determinant of intraguild predation in top predators. Behav Ecol Socbiol 65:1709-1714. doi:10.1007/s00265-011-1178-2

Millon A, Petty SJ, Lambin X (2010) Pulsed resources affect the timing of first breeding and lifetime reproductive success of tawny owls. J Anim Ecol 79:426-435. doi:10.1111/j.1365-2656.2009.01637.x

Morosinotto C, Thomson RL, Korpimäki E (2010) Habitat selection as an antipredator behaviour in a multi-predator landscape: all enemies are not equal. J Anim Ecol 79:327-333. doi:10.1111/j. 1365-2656.2009.01638.x

Palomares F, Delibes M, Revilla E, Calzada J, Fedriani JM (2001) Spatial ecology of Iberian lynx and abundance of European rabbits in southwestern Spain. Wildl Monogr 148:1-36

Penteriani V (2002) Goshawk nesting habitat in Europe and North America: a review. Ornis Fenn 79:149-163

Penteriani V, Delgado MM (2008) Brood-switching in eagle owl Bubo bubo fledglings. Ibis 150:816-819. doi:10.1111/j.1474-919X. 2008.00831.x
Penteriani V, Delgado MM (2009a) The dusk chorus from an owl perspective: eagle owls vocalize when their white throat badge contrasts most. PLoS One 4(4):e4960. doi:10.1371/journal. pone. 0004960

Penteriani V, Delgado MM (2009b) Owls may use faeces and prey feathers to signal current reproduction. PLoS One 3(8):e3014. doi:10.1371/journal.pone.0003014

Penteriani V, Delgado MM (2011) Birthplace-dependent dispersal: are directions of natal dispersal determined a priori? Ecography 34:729-737. doi:10.1111/j.1600-0587.2010.06773.x

Penteriani V, Delgado MM (2012) There is a limbo under the moon: what social interactions tell us about the floaters' underworld. Behav Ecol Sociobiol 66:317-327. doi:10.1007/s00265-011-1279-y

Penteriani V, Faivre B (1997) Breeding density and nest site selection in a goshawk Accipiter gentilis population of the Central Apennines (Abruzzo, Italy). Bird Study 44:136-145. doi: 10.1080/00063659709461049

Penteriani V, Delgado MM, Maggio C, Aradis A, Sergio F (2004) Development of chicks and pre-dispersal behaviour of young in the eagle owl Bubo bubo. Ibis 147:155-168. doi:10.1111/j.1474919x.2004.00381.x

Penteriani V, Delgado MM, Alonso-Alvarez C, Sergio F (2007) The importance of visual cues for nocturnal species: eagle owls signal by badge brightness. Behav Ecol 18:143-147. doi:10.1093/ beheco/arl060

Penteriani V, Delgado MM, Maggio C, Alonso-Alvarez C, Holloway GJ (2008a) Owls and rabbits: selective predation against substandard individuals by a sit-and-wait predator. J Avian Biol 39:215-221. doi:10.1111/j.0908-8857.2008.04280.x

Penteriani V, Lourenço R, Delgado MM (2008b) El fenómeno de la colonización de Doñana por parte del búho real: patrones espacio-temporales de la población y efectos sobre las comunidades de aves y mamíferos. Final Report, C.S.I.C.-Junta de Andalucía EXPTE:700/2005/M/00

Penteriani V, Ferrer M, Delgado MM (2011a) Floater strategies and dynamics in birds, and their importance in conservation biology: towards an understanding of nonbreeders in avian populations. Anim Conserv 14:233-241. doi:10.1111/j.1469-1795.2010. 00433. $\mathrm{x}$

Penteriani V, Kuparinen A, Delgado MM, Lourenço R, Campioni L (2011b) Individual status, foraging effort and need for conspicuousness shape behavioural responses of a predator to moon phases. Anim Behav 82:413-420. doi:10.1016/j.anbehav.2011.05.027

Penteriani V, Lourenço R, Delgado MM (2012) Eagle owls in Doñana: a conservation dilemma or not? Br Birds 105:88-95

R Development Core Team (2009) R: a language and environment for statistical computing. R Foundation for Statistical Computing, Vienna

Racović A, Mikuska T (2009) Population size, distribution and habitat selection of the white-tailed eagle Haliaeetus albicilla in the alluvial wetlands of Croatia. Biologia 64:1-9. doi:10.2478/s11756008-0011-0

Rohner C (1997) Non-territorial 'floaters' in great horned owls: space use during a cyclic peak of snowshoe hares. Anim Behav 53:901-912. doi:10.1006/anbe.1996.0381

Sergio F, Blas J, Forero M, Fernández N, Donázar JA, Hiraldo F (2005) Preservation of wide-ranging top predators by siteprotection: black and red kites in Doñana National Park. Biol Conserv 125:11-21. doi:10.1016/j.biocon.2005.03.002

Sergio F, Marchesi L, Pedrini P, Penteriani V (2007) Coexistence of a generalist owl with its intraguild predator: distance-sensitive or habitat-mediated avoidance? Anim Behav 74:1607-1616. doi: 10.1016/j.anbehav.2006.10.022

Smith SM (1978) "Underworld" in a territorial sparrow: adaptive strategy for floaters. Am Nat 112:571-582 
Stamp J, Krishnav VV, Reid ML (2005) Search costs and habitat selection by dispersers. Ecology 86:510-518. doi:10.1890/04-0516

Stutchbury BJ (1991) Floater behaviour and territory acquisition in male purple martins. Anim Behav 42:435-443. doi:10.1016/ S0003-3472(05)80042-9

Sunde P, Bølstad MS, Desfor KB (2003) Diurnal exposure as a risk sensitive behaviour in tawny owls Strix aluco? J Avian Biol 34:409-418. doi:10.1111/j.0908-8857.2003.03105.x
Terborgh J (1989) Where have all the birds gone?. Princeton University Press, Princeton

Tobler M, Smith HG (2004) Specific floater home ranges and prospective behaviour in the European starling, Sturnus vulgaris. Naturwissenschaften 91:85-89. doi:10.1007/s00114-003-0486-4

Zuur AF, Ieno EN, Walker NJ, Saveliev AA, Smith GM (2009) Mixed effects models and extensions in ecology with $\mathrm{R}$. Springer, New York 